\title{
Angiossarcoma Epitelióide Ósseo: Relato de um Caso, com Estudo Imuno-Histoquímico.*
}

\author{
Epithelioid Angiosarcoma of Bone: Report of a Case with Immunohistochemical Study*
}

Cláudia Regina G. C. M. de Olineira'; Olavo Pires de Camargo; Tarcísio E. P. Barros Fillo3 ; Reginaldo P. Olineira4; AlBERTO T. CROCF; ; AndRÉ MATIAS BAPTISTA ${ }^{6}$

\section{RESUMO}

Angiossarcoma primário do osso é muito raro, representando menos de $1 \%$ de todos os angiossarcomas ${ }^{(4)}$.

Neoplasias vasculares também são incomuns, ocorrendo em $14 \%$ dos tumores malignos primários do osso. Os autores relatam caso em coluna lombar que merece atenção porque inicialmente tratava-se de um hemangioendotelioma, um tumor de malignidade intermediária, definido pelos critérios estabelecidos por Stout ${ }^{(11)}$. Foi tratado com embolização local e radioterapia. Após dez anos, recidivou, com maior grau de malignidade, fenômeno interpretado como progressão tumoral, com características de Angiossarcoma epitelióide. O estudo imuno-histoquímico revelou positividade para marcadores vasculares. (Fator VIII, CD31 e CD34). O paciente evoluiu com metástases pulmonares. Em revisão bibliográfica, não foi encontado nenhum relato de caso semelhante, tendo em vista a longa evolução e progressão tumoral após dez anos de seguimento e expressão do fenotipo epitelióide.

Descritores: Angiossarcoma. Neoplasia vascular óssea.

\section{SUMMARY}

Primary angiosarcoma of bone is rare and accounts for less than $1 \%$ of all angiosarcomas ${ }^{(4)}$.

Vascular bone neoplasms represent $1,4 \%$ of primary malignant bone tumors. The authors describe an unusual case of bone angiosarcoma located in the spine.

The diagnosis was initially hemangioendothelioma, a borderline endothelial vascular tumor, as stated by Stout(11). The lesion was treated by local embolization and radiation therapy.

The tumor recurred locally ten years later as a high-grade

angiosarcoma, showing epithelioid features, which indicates tumor progression.

Immunohistochemical studies were positive for vascular markers such as factor VIII, CD31 and CD 34. The patient developed lung metastasis.

I was not observed in the literature any other case with ten-year follow-up and tumor progression with epithelioid features.

Keywords: Angiosarcoma. Vascular tumors.
*Trabalho realizado na Seção de Anatomia Patológica do Instituto de Ortopedia e Traumatologia do Hospital das Clínicas da Faculdade de Medicina da Universidade de São Paulo (IOTHC-FMUSP).

1. Chefe da Seção de Anatomia Patológica

2. Chefe do Grupo de Tumores

3. Chefe do Grupo de Coluna Vertebral

4. Chefe do Grupo de Coluna Cervical e Raquimedular

5. Médico Assistente do Grupo de Tumores

6. Médico Estagiário do Grupo de Tumores
* This study was carried out in the Pathological Anatomy Department, Orthopedics and Traumatology Institute, "Hospital das Clínicas", University of São Paulo College of Medicine (IOT-HCFMUSP).

1. Head, Pathological Anatomy Department

2. Head, Tumor Group

3. Head, Spinal Column Group

4. Head, Cervical Group

5. Assistant Physician, Tumor Group

5. Assistant Physician, Tumor Group
6. Trainee Physician, Tumor Group 


\section{INTRODUÇÃO}

Angiossarcoma é uma neoplasia maligna, composta de células endoteliais que tem características vasoformadoras ${ }^{(4)}$. Somente $1.4 \%$ dos tumores primários malignos ósseos são classificados como angiossarcomas ${ }^{(3)}$. Em 1943, Stout ${ }^{(11)}$ diferenciou morfologicamente pelo menos dois tipos de tumores malignos de vasos sangüíneos, o hemangioendotelioma e o hemangiopericitoma, onde o primeiro se caracterizava pela proliferação de células endoteliais e o segundo pela proliferação de células pericíticas. Hemangioendotelioma e angiossarcoma eram usados no passado como sinôminos. Unni et al (12), concordando com Ackerman e Spjut ${ }^{(10)}$ consideraram que os tumores vasculares endoteliais malignos do osso poderiam ser classificados como uma única entidade.

Eles preferiram o termo hemangioendotelioma para essa entidade porque o termo angiossarcoma denotava um maior grau de malignidade o que era evidente em apenas alguns dos casos. De fato o curso desses tumores era variável, predominantemente progressivo e fatal $^{(7)}$.

Hemangioendotelioma, de acordo com o critério definitivo por Stout pode ocorrer em qualquer grupo etário, tendo uma predileção para o sexo masculino, envolvendo mais freqüentemente os ossos longos tubulares, principalmente a região proximal do fêmur ${ }^{(13)}$. Comumente aparecem como lesão solitária, mas podem ser multicêntricos, ${ }^{(4)}$. Quando multicêntricos, parecem ter melhor prognóstico $^{(4)}$.

Radiograficamente são lesões líticas ocorrendo com pouca ou nenhuma neoformação óssea reacional.

A cortical pode estar afilada ou destruída, com extensão para partes moles. "Shunts" arteriovenosos podem ocorrer e a arteriografia pode ser de valor em diferenciar tumores vasculares de não vasculares e em determinar a extensão da invasão em partes moles.

O diagnóstico diferencial radiograficamente inclui carcinoma de células claras, carcinoma metastático, sarcoma de Ewing, hemangiopericitoma, ostessarcoma, linfoma, displasia fibrosa e cisto ósseo aneurismático(6).

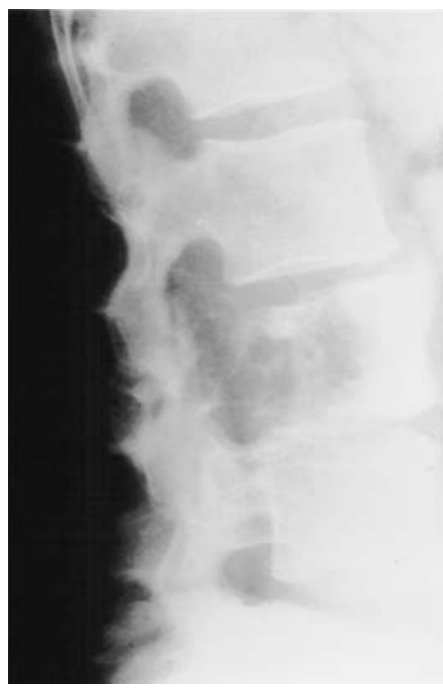

\section{INTRODUCTION}

Angiosarcoma is a malignant neoplasia, composed by endothelial cells with vasoforming characteristics (4). Only $1.4 \%$ of the malignant primary tumors of bone are categorized as angiosarcomas (3). In 1943, Stout (11) has morphologically distinguished at least two types of malignant tumors in the blood vessels, the hemangioendothelioma and the hemangiopericytoma; the former was characterized by proliferation of endothelial cells and the latter of pericytic cells. Hemangioendothelioma and angiosarcoma were previously used as synonyms. Unni et al. (12), as Ackerman and Spjut (10), considered that the malignant endothelial vascular tumors of bone could be classified as a single entity.

They choose the term hemangioendothelioma since angiosarcoma denoted a higher degree of malignancy evident in a few cases. Actually, these tumors evolution was variable, predominantly progressive and lethal (7).

The hemangioendothelioma, according to the final criterion of Stout, is observed in all age groups, mainly in males, more frequently in the long bones, usually the femur proximal region (13). They appear as a single lesion, but they can be multicentric (4). In these cases, prognosis is apparently better (4).

Radiographically, they appear as lithic lesions which occur with little or none reactional bone neoformation.

The cortical can be sharpened or destructed, reaching the soft tissues. Arteriovenous shunts can occur and arteriography can be useful to distinguish vascular and non-vascular tumors and to determine the extension of the invasion in the soft tissues.

Radiographically, the differential diagnosis includes clear cell carcinoma, metastatic carcinoma, Ewing sarcoma, hemangiopericytoma, osteosarcoma, Iymphoma, fibrous dysplasia and aneurismal bone cyst (6).

Fig. 1 - Hemangioendotelioma ósseo em coluna lombar ( $L 3)$

Figure 1. Hemangioendothelioma of bone in the lumbar spine (L3) 


\section{RELATO DO CASO}

Um paciente do sexo masculino, de trinta e dois anos, foi atendido no Instituto de Ortopedia e Traumatologia do Hospital das Clínicas da FMUSP, em 1989 com história de dor localizada em região da coluna, com paraparesia há cinco meses.

A radiografia simples mostrava em coluna lombar a nível de L.3, lesão radiolucente, com trabeculações paralelas e longitudinais, destruição da cortical, sem esclerose e com extensão para partes moles. (Fig.-1).

A tomografia computadorizada confirmava o comprometimento da cortical e a ressonância magnética evidenciava a extensão em partes moles. Não havia comprometimento de outros ossos.

O espécime de biópsia foi diagnosticado como hemangioendotelioma, sendo realizada embolização local e radioterapia uma vez que a lesão era irressecável pela sua localização.

O exame microscópico revelava neoplasia de natureza vascular, caracterizada por vasos anatomosados com células endoteliais atípicas (Fig.-2) e projeções papilares intravasculares.

\section{CASE REPORT}

In 1989, a thirty-two year-old male patient was seen in the Orthopedics and Traumatology Institute, "Hospital das Clínicas", FMUSP, complaining of pain in the spinal column and five-month duration paraparesis.

The $X$-rays revealed a radiolucent lesion spreading to the soft tissues in L3, lumbar column, parallel and longitudinal trabeculation, cortical destruction, no sclerosis (Fig.-1).

The computerized tomography confirmed the cortical involvement and the magnetic ressonance evidenced the soft tissues extension. No other bones were involved. The biopsy evidenced hemangioendothelioma. Due to the localization, the lesion was unresectable thus local embolization was carried out and radiotherapy was instituted. The microscopic analysis evidenced a vascular neoplasia characterized by vessel anastomosis with atypical endothelial cells (Fig. 2) and intravascular papillary projections.

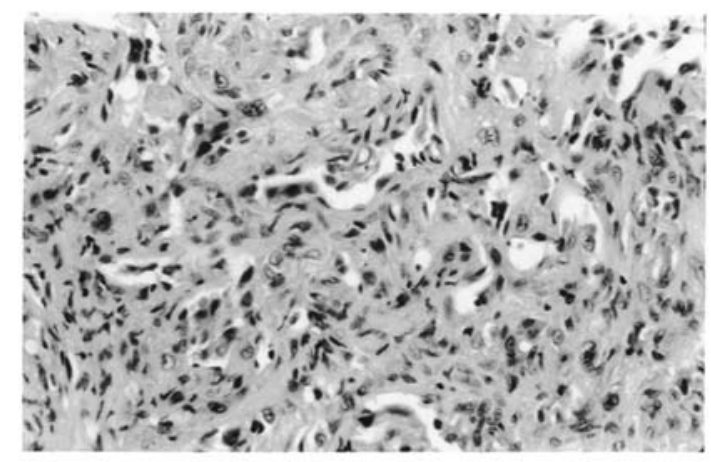

Fig. 2 - Proliferação vascular com presença de células endoteliais atípicas (400X)

Figure 2. Vascular proliferation with atypical endothelial cells

Mitoses eram raras e não havia necrose. Portanto foi classificado como hemangioendotelioma e não angiossarcoma.

Após dez anos de seguimento clínico, o paciente retornou com quadro clínico de dor, revelando possivelmente uma recidiva.

Atualmente, feitos exames de RX e tomografia computadorizada, constatou-se crescimento da lesão, com aspecto destrutivo (Fig.3) e grande extensão para partes moles, revelando maior agressividade local. O paciente apresentava também quadro de síndrome de cauda eqüina. Foi realizado tratamento cirúrgico com laminectomia ampla e descompressiva e radioterapia.

O exame microscópico revelou ninhos sólidos de células epitelióides que ocasionalmente mostravam maior grau de atipia, com citoplasma eosinófilo, apresentando por vezes intensa
Rare mitoses and no necrosis were observed. The condition was diagnosed as hemangioendothelioma rather than angiosarcoma.

After a ten-year follow-up, the patient presented a painful clinical picture suggesting recurrence.

X-rays and computerized tomography showed that a lesion with destructive aspect had grown (Fig. 3) and spread to the soft tissues revealing more local aggressiveness. The patient also presented the cauda equina syndrome. Surgery with extensive and decompressive laminectomy was carried out and radiotherapy was instituted. The microscopical examination revealed solid clusters within the epithelioid cells that occasionally showed a greater degree of atypia, with eosinophilic cytoplasm sometimes with intense vascularization. 


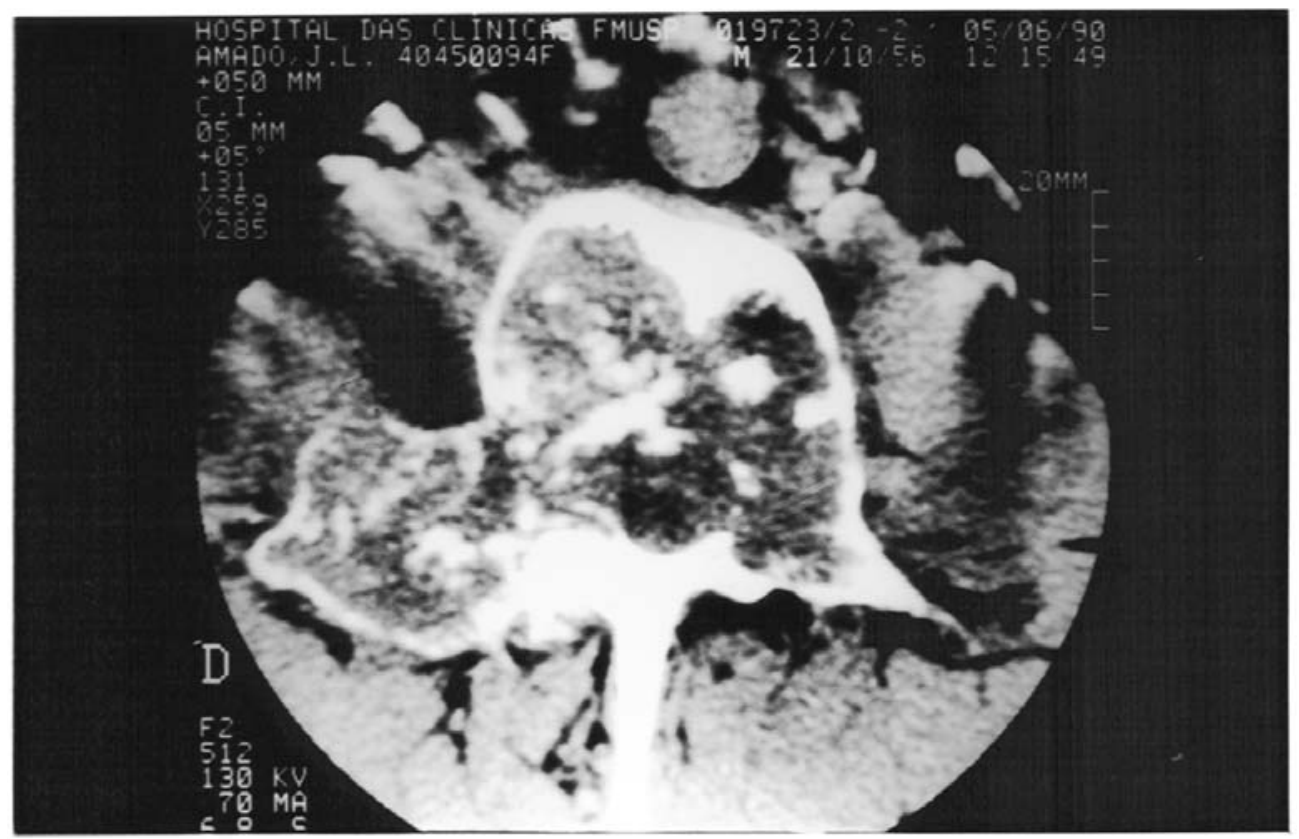

Fig. 3 - Tomografia computadorizada mostrando destruição da cortical.

Figure 3. Computerized tomography showing cortical destruction

vascularização. Havia focos de necrose e moderado número de mitoses. As características epitelióides desse tumor mimetizavam carcinoma metastático, no osso (Fig.-4). O exame imunohistoquímico foi realizado e as células epitelióides foram positivas para Fator VIII, CD31 e CD34, que são marcadores vasculares e de células endoteliais, caracterizando neoplasia de natureza vascular. Não houve expressão de marcadores epiteliais, como queratina e EMA, afastando a hipótese de carcinoma.

O diagnóstico anatomopatológico foi de Angiossarcoma epitelióide. O paciente foi estadiado, encontrando-se múltiplas lesões pulmonares, com caracteres de metástase pulmonar.

\section{DISCUSSÃO}

Dorfman et $\mathrm{al}^{(5)}$ tem mostrado que o osso é raramente o sítio de neoplasias de vasos sangüíneos e linfáticos, apesar de serem ricamente vascularizados. Tumores malignos vasculares constituem menos de $1 \%$ das neoplasias malignas primárias do osso, na série relatada por Dahlin(2).
Necrotic foci and a moderate number of mitoses were observed. The epithelioid characteristics of the tumor resemble metastatic carcinoma of bone (Fig. 4). The immunohistochemical analysis was carried out and the epithelioid cells were positive for Factor VIII, CD31 and CD34, vascular markers of the endothelial cells, characterizing vascular neoplasia. There was no expression of epithelial markers, as keratin and EMA, disproving the carcinoma hypothesis. The anatomopathological diagnosis was epithelioid angiosarcoma. The patient was staged, and multiple pulmonary lesions were found featuring pulmonary metastasis

\section{DISCUSSION}

Dorfman et al. (5) have shown that the bone seldom is the site of choice of blood and lymphatic vessels neoplasias, though they are highly vascularized. Vascular malignant tumors constitute less than $1 \%$ of the primary malignant neoplasias of bone, in the series reported by Dahlin (2). 


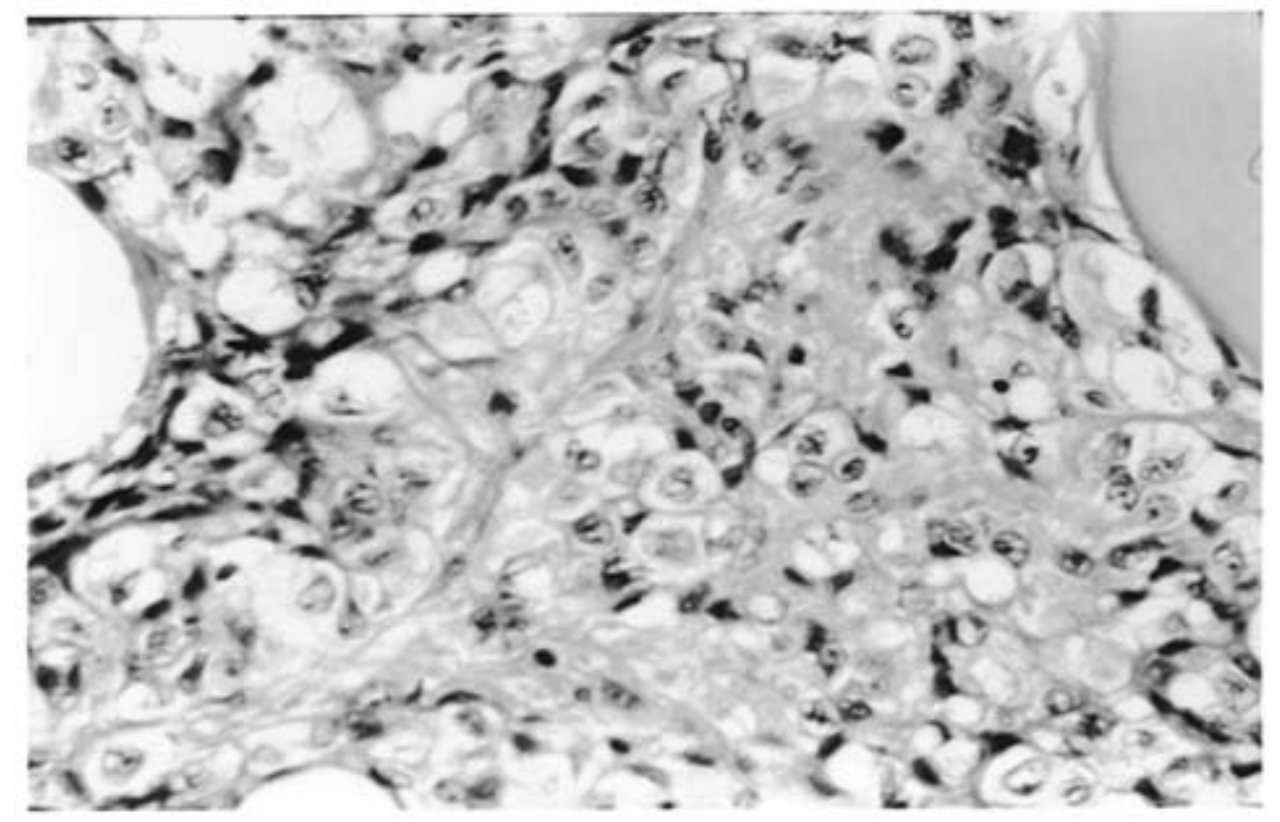

Fig. 4 - Angiossarcoma epitelióide, simulando carcinoma ( 400X)

Figure 4. Epithelioid angiosarcoma resembling carcinoma (400x)

Nós concordamos com outros autores ${ }^{(13,6)}$ de que os tumores vasculares malignos do osso são uma entidade distinta, com curso clínico imprevisível. Nessa caso relatado o diagnóstico inicial foi de hemangioendotelioma, de acordo com critérios morfológicos definidos por Stout ${ }^{(11)}$ que se baseia em:

1) Células endoteliais atípicas, em maior número delineando a parede dos vasos.

2) Tendência para formar lúmen vascular e anastomoses

É difícil determinar o grau de malignidade numa amostra de biópsia por geralmente haver graus variados num mesmo tumor.

Unni et $\mathrm{al}^{(12)}$ em revisão de 22 casos de hemangioendotelioma de osso, dividiu esses tumores em três distintos graus, revelando que o maior indicador de prognóstico foi o grau de anaplasia.

Hastman e Stewart ${ }^{(8)}$ enfatizaram a possibilidade de curso benigno em alguns casos, com longa sobrevida após cirurgia quimioterapia e radioterapia. O prognóstico para esses tumores, entretanto, ainda continua pobre, com sobrevida em 5 anos de $26 \%{ }^{(7)}$. A possibilidade de curso indolente com longa sobrevida é demonstrada em alguns casos, com seguimento de oito e catorze
We agree with other authors $(13,6)$ that the malignant vascular tumors of bone are a distinct entity, with an unpredictable clinical evolution. In this case, the initial diagnosis was hemangioendothelioma, according to the morphological criteria of Stout (11) as follows:

1) Higher number of endothelial atypic cells outlining the vessels walls.

2) A tendency to form vascular lumen and anastomosis

It is difficult to determine the degree of malignancy in biopsies since there are several degrees in the same tumor. Unni et al. (12), reviewing 22 cases of hemangioendothelioma of bone, categorized these tumors in three different degrees, revealing that the best indicator for the prognosis was the degree of anaplasia. Hastman and Stewart (8) emphasized the possibility of a benign evolution with long survival after surgery, chemotherapy and radiotherapy. The prognosis for these tumors, however, is still poor, with 26\% 5-year survival (7). The possibility of an indolent course with long survival was shown in some cases with eight- and fourteen-year follow-up. However, the disease seems to be aggressive and lethal, as Volpe and Mazabraud have shown (13), even after surgery, radiotherapy 
anos Entretanto a doença parece ser agressiva e rapidamente fatal, como demostrado por Volpe e Mazabraud(13), mesmo com tratamento incluindo cirurgia, radioterapia e quimioterapia.

Nesse caso que apresentamos, após dez anos observou-se uma modificação no padrão histológico, em relação à primeira apresentação dessa neoplasia. Além do aumento do grau de malignidade, pela presença de mitoses, atipia e necrose, identificouse também o fenótipo epitelióide, com citoplasma acidofílico devido à presença de numerosos citofilamentos. Os citofilamentos mantém o citoesqueleto dos vasos submetidos a alta pressão, significando um "status funcional" da célula neoplásica.

Rosai et al (9) chamaram a atenção por esse aspecto epitelióide das células, mas foi em 1982, que Weiss e Enzinger propuseram o termo hemangioendotelioma e angiossarcoma epitelióide.

A imuno-histoquímica é um exame de grande valor para auxiliar no diagnóstico diferencial desses tumores com carcinoma metastático. Em alguns casos de hemangioendoteliomas pode haver positividade para marcadores epiteliais.de baixo peso molecular, mas nos carcinomas não há positividade para marcadores vasculares ( como Fator VIII, CD 31 e CD 34).

Os tumores vasculares malignos tem evolução clínica imprevisível sendo que mesmo um tumor de baixo grau pode metastizar após muitos anos de evolução. A modificação do grau de malignidade nesse caso apresentado, pode refletir um fenômeno de progressão tumoral, que já é descrito em outros tumores como osteossarcoma, tumor de células gigantes e condrossarcoma(3), ressaltando mais um aspecto do comportamento imprevisível dos tumores vasculares malignos ósseos.

O tratamento nesses tumores deve ser cirúrgico, com ressecção ampla da lesão, nos casos de alto grau, podendo-se complementar com radioterapia, em lesões de difícil acesso ou quando não se consegue obter margem cirúrgica livre.

No caso apresentado por ser inicialmente um tumor de baixo grau (hemangioendotelioma) tentou-se a embolização da lesão, e radioterapia com boa resposta inicial. Após dez anos, com a recidiva e com maior grau de malignidade, verificamos que a doença pode ser progressiva, agressiva e fatal, necessitando de abordagem cirúrgica e radioterapia. A quimioterapia não tem sido usado como tratamento adjuvante. and chemotherapy. In this case, a modification in the histological pattern was observed ten years after the first presentation. Besides the higher degree of malignancy with the presence of mitosis, atypia and necrosis, an epithelioid phenotype was also identified showing acidophilic citoplasm due to the presence of numerous cytofilaments. The cytofilaments maintain the cytoskeleton of the vessels under high pressure meaning a "functional status" of the neoplastic cell.

Rosai et al. (9) called the attention to this epithelioid aspect of the cells, but only in 1982, Weiss and Enzinger proposed the terms hemangioendothelioma and epithelioid angiosarcoma. The immunohistochemistry is valuable in the differential diagnosis of these metastatic carcinomas. In some cases of hemangioendotheliomas, epithelial markers of low molecular weight may be present, but no vascular markers (as Factor VIII, CD31 and CD34) are observed in the carcinomas.

The malignant vascular tumors have unpredictable clinical evolution, and even a low grade tumor can form metastasis after several years evolution. The modification of the malignancy degree in our case may represent a tumoral progression phenomenon already described in other tumors as osteosarcomas, giant cell tumors, and chondrosarcomas (3), emphasizing another aspect of the unpredictable behavior of the malignant vascular tumors of bone.

These tumors treatment demands surgery, with extensive ressection of the lesion in the high degree cases; complementary radiotherapy can be used in difficult to reach lesions or when free surgical margins cannot be obtained.

In our case, as the tumor was firstly a low degree tumor (hemangioendothelioma), embolization of the lesion was carried out and radiotherapy was instituted with good initial response. After ten years we observed that the disease can be progressive, aggressive and lethal, and surgery and radiotherapy are the necessary approaches. Chemotherapy has not been considered as an adjuvant treatment. 


\section{REFERÊNCIAS}

1. COHEN, P.R., RAPINI, R.P., FARHOOD, A.I.: Expression of the human hematopoietic progenitor cell antigen CD 34 in vascular and spindle cells tumors. J. Cutan Pathol 20: 15-20, 1993.

2. DAHLIN, D.C.: Vascular tumors of bone: Bone Tumors: General Aspect and Data em 421 cases, 3rd ed. Springfiield, Illinois. 144-145, 1978:

3. DORFMAN, H. D., CZERNIAK B., Bone cancer, CANCER 75:203-210, 1995.

4. DORFMAN, H. D., CZERNIAK, B.: Vascular tumors of bone; Bone Tumors, St LOUIS, CV MOSBY. 795-797, 1998.

5. DORFMAN, H. D, STEINER, L.C., JAFFE, H.L., Vascular tumors of Bone. Hum Pathol. 2:349-376, 1971.

6. DUNLOP, J.: Malignant Hemangioendothelioma of Bone, The Journal of Bone and Joint Surgery. 59-A, n 6: 832-834, 1977.

7. GARCIA MORAL, C.A: Malignant hemangiendothelioma of bone. Review of world literature and report of two case. Clin Orthop. 82:7079, 1972.

8. HARTMANN, W. H., STEWART, F.W.: Hemangioendothelioma of bone. Unusual tumor characterized by indolent course. Cancer 15:846-854, 1962.

9. RONAI, J., GOLD, J., LANDY, R. The histiocytoid hemangiomas: A unifying concept embrasing several previously described entites of skin, soft tissue, large vessels, bone and heart. Hum Pathol. 10:707730, 1979.

10.SPJUT H.D., DORFMAN R.E., FECHNER R.E., Ackerman L.V. Tumors of Bone and Cartilage. In: Atlas of Tumor Pathology. Sect. 2 fasc. 4. WASHINGTON D.C: Armed Forces Institute of Pathology. 334-340, 1971

11.STOUT, A. P.: HEMANGIO-ENDOTHELIOMA: a tumor of blood vessels featuring vascular endotheleal cells. Ann Surg. 118; 445-464, 1943.

12.UNNI, K.K., IVINS, J.C., BEABOUT, J.W., DAHLIN, D.C.: Hemangioma hemangiopericytoma and hemangioendothelioma of bone. Cancer 27:1403-1414, 1971.

13.VOLPE, R., MAZABRAUD, A.: Hemangioendothelioma (Angiosarcoma) of Bone. Cancer 49:727-736, 1982

14.WEISS and ENZINGER. Epithelioid hemangioendothelioma. Cancer 50: $971-981,1982$. 